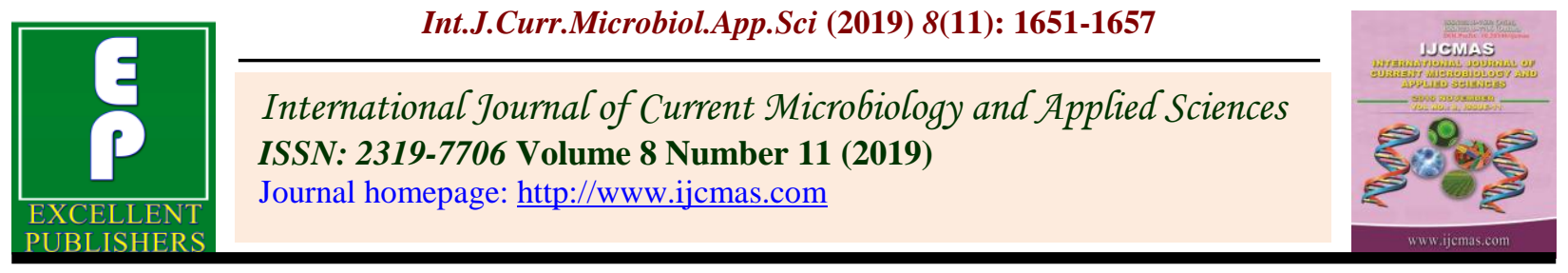

Original Research Article

https://doi.org/10.20546/ijcmas.2019.811.191

\title{
Evaluation of Azotobacter Isolates of Fodder Grasses and its Effect on Sweet Corn Crop
}

\author{
A.R. Potdar*, T.K. Narute, S.N. Hasabanis and A.R. Kedar \\ Department of Plant Pathology and Agricultural Microbiology, College of Agriculture, \\ Pune,Mahatma Phule Krishi Vidyapeeth, Maharashtra State, India \\ *Corresponding author
}

Keywords

Azotobacter,

Fodder grasses,

Nitrogen fixing ability, Sweet corn, Yield

Article Info

Accepted:

12 October 2019

Available Online:

10 November 2019

\section{A B S T R A C T}

A field experiment was conducted to evaluate the effect of Azotobacter isolates collected from rhizospheric soil of fodder grasses viz., Napier grass, Marvel grass, Anjan grass, Stylo grass, Johnson grass, Fodder jowar and Fodder maize as a seven treatments. The morphological, biochemical and cultural characteristics of individual isolate was studied. The nitrogen fixing ability of these seven isolates were carried out in which Azotobacter isolated from Napier grass showed highest nitrogen fixing ability with $19.62 \mathrm{mg} / \mathrm{g}$ of sucrose consumed which was followed by Azotobacter isolated from Johnson grass with $18.21 \mathrm{mg} / \mathrm{g}$ of sucrose consumed. The application of lignite based biofertilizer of individual Azotobacter isolates as a seed treatment to the sweet corn seeds showed increased trend in various growth parameters in which the yield of sweet corn obtained due to treatment of Azotobacter isolated from rhizospheric soil of Napier grass found significantly higher (265.87 g/plant) than rest of treatments. Hence, the Azotobacter strain of Napier grass can be commercialized as an efficient biofertilizerstrain of Azotobacter.

\section{Introduction}

Maize (Zea mays L.), is considered as Queen of Cereals. It is the world's third most important crop after wheat and rice. It has global importance in world agriculture. It contributes about $20 \%$ of worlds total cereal production. It is one of the most versatile crops in nature, which can be grown over wide range of climatic conditions. India produces about $2 \%$ of world's total maize production. The total maize production of India in 201718 was 21.93 MMT (Anonymous, 2017). There are six major types of maize as dent corn, flour corn, flint corn, pod corn, pop corn and sweet corn. Sweet corn (Zea mays var. saccharata) is also called as sugar corn and pole corn. It is a cereal with 
high sugar content. The sweet corn grain contains $16 \%$ carbohydrates, $6 \%$ protein, $3.22 \%$ sugar, $2.7 \%$ dietary fiber, $7 \%$ total fat, vitamin C $11 \%$, vitamin B-6 5\%, potassium $270 \mathrm{mg} / 100 \mathrm{~g}$, iron $2 \%$, magnesium $9 \%$.

Sweet corn requires more amount of nutrients hence it is also called as heavy feeder. Nitrogen $(\mathrm{N})$ is a major macronutrient which affects growth and yield of sweet corn crop. To fulfill the nutrient requirement of crop farmers are using higher doses of chemical fertilizers. The applications of heavy amount of chemical fertilizers are deteriorating soil and environment. Hence to overcome this problem use of biofertilizers is one of the ways in organic farming to increase crop yield without damaging the environment and soil health.

Azotobacter is the non-symbiotic, free living, aerobic, heterotrophic bacterium. It fixes atmospheric nitrogen in the form of ammonium ions in the soil, it also produces plant growth promoting hormones like gibberellins, cytokinin and auxin (Azcon et al., 1975; Kukreja et al., 2004), ammonia, vitamins and growth promoting substances which are responsible for seed germination ( $\mathrm{J}$ Gonzalez-Lopez et al., 1986), protection against root pathogens (Varma et al., 2001; Sindhu et al., 2009). Bacterium fixes an average of $10-15 \mathrm{~kg}$ N/ha per year (Henzell and Norris, 1962). It found in soil and rhizosphere of many crops. Its population varies from negligible to $10^{4} / \mathrm{g}$ of soil. It is founded that it fixes about $10 \mu \mathrm{g}$ of nitrogen by consuming $1 \mathrm{~g}$ of glucose. It is able to grow at a $\mathrm{pH}$ range of 4.8-8.5 and fixes nitrogen at optimum $\mathrm{pH}$ of 7.0-7.5 (Dilworth et al., 1988)

Sweet corn is one of the hosts for Azotobacter. Many times the Nitrogen fixing bacteria are isolated from different plants including vegetables, cereals, pulses, fruit plants for their efficiency test. However the fodder grasses are not considered so far for isolating such microbes. The fodder grasses thrive well in all adverse climatic conditions. Their rhizospheric soil play key role in nutrient management. It contains all beneficial microbes which help grasses to survive in all climatic condition, Hence the present research was planned to isolate Azotobacter from rhizospheric soil of fodder grasses, their morphological study and nitrogen fixing efficiency of individual Azotobacter isolate.

\section{Materials and Methods}

The present investigation was undertaken for the evaluation of Azotobacter isolates of fodder grasses and its effect on growth parameters, nutrient uptake and yield of sweet corn var. Madhu-5. The field trial was conducted at Department of Plant Pathology and Microbiology, College of Agriculture, Pune-411005 during 2018-19. The live seven fodder grass samples viz., Napier grass, Marvel grass, Anjan grass, Stylo grass, Johnson grass, Fodder jowar and Fodder maize were collected from All India Coordinated Research Project on Forage Crops and Utilization, central campus Mahatma Phule Krishi Vidyapeeth, Rahuri and Agronomy field, College of Agriculture, Pune. The eight treatments were replicated thrice and are detailed under table 1.

The fresh rhizospheric soil sample of individual grass was collected for isolation of Azotobacter in laboratory. The isolation of Azotobacter was done on Jensen's media by dilution and plating method. The isolated Azotobacter plates were kept in BOD incubator at $28 \pm 2{ }^{\circ} \mathrm{C}$ temperature for 3 days. After incubation period the typical colony growth was observed and their purity was verified by simple staining and Koperloff and Berman's modified method of Gram staining (Salle, 1967). Slants of Jensen's media were prepared and the pure culture was maintained 
by periodical sub culturing on Jensen's agar slants. The morphological, cultural and biochemical characters of individual Azotobacter isolates was studied by following standard procedures. The nitrogen fixing ability of individual Azotobacter isolate in laboratory condition was calculated by using Micro-Kjeldhal method.

By using individual Azotobacter isolates, seven lignite based biofertilizer were prepared which then used for seed treatment to sweet corn seeds. The experimental plot was ploughed to a medium depth with clod crushing, ridges and furrows were opened at a distance of $60 \mathrm{~cm}$. The initial soil samples were collected for analysis of available major nutrients; nitrogen $(\mathrm{N})$, phosphorous $(\mathrm{P})$ and potassium (K). The recommended FYM was added @ 15-20 tones/ha. and irrigated. After achieving the field capacity, the biofertilizer treated seeds were sown in three replications. Immediately, after sowing, field was irrigated. The recommended dose of fertilizer of sweet corn crop is $120: 60: 40 \mathrm{~kg} / \mathrm{ha}$. (N:P:K). Only basal dose of full potassium and phosphorus was given as per the recommended dose except control plot through the straight fertilizers i.e. Single Super Phosphate and Murate of Potash. Nitrogenous fertilizer was not given to the any treatment plot to assess the performance of nitrogen fixing efficiency of individual Azotobacter isolate alone. The subsequent irrigations were given as per the irrigation schedule. The moisture of field was maintained throughout the growing period of crop. Thinning was carried out after 10 days of sowing to maintain plant population and healthy seedlings. Hand weeding carried out to make weed free plot.

The observation on seed germination, height of plant, number of leaves, length of leaves, width of leaves, number of cobs, cob yield per plant, total dry matter weight of plant and nitrogen uptake by the sweet corn were recorded manually on five randomly selected representative plants from each plot of each replication separately as well as yield and yield attributing characters were recorded as per the standard method. Yield attributes were also recorded at physiological maturity stage. The data obtained from different observations were calculated as per Randomized Block Design (RBD) by using the standard statistical methods (Panse and Sukhatme, 1967) for its statistical significance.

\section{Results and Discussion}

\section{Morphological, cultural and biochemical characters of individual Azotobacter isolate}

An individual Azotobacter isolate showed rod to spherical shape, non acid fast, non spore former, milky white to white colonies with striation and cyst formation with dark brown to black pigmentations and were identified as Azotobacter spp. It showed positive result to catalase test. The colonies were circular, smooth, undulating and convex.

\section{Plant growth parameters and yield attributes}

The data was recorded at 30,60 and 90 days after sowing with respect to different growth parameters. The data in table 1 is analyzed by using standard statistical method. Among the different treatments highest seed germination percentage was recorded in treatment $T_{1}$ with Azotobacter isolated from rhizospheric soil of Napier grass $(89.47 \%)$ which is followed by treatment $\mathrm{T}_{5}$ with Azotobacter isolated from rhizospheric soil of Johnson grass (78.07\%). The maximum plant height $(144.23 \mathrm{~cm})$, number of leaves (12.60), length of leaf (95.89 $\mathrm{cm}$ ), width of leaf (10.01) and number of cobs (2.00) were observed in treatment $T_{1}$. Maximum cob yield (265.87 $\mathrm{g} \mathrm{plant}^{-1}$ ) was recorded in treatment $T_{1}$ which is followed by treatment $\mathrm{T}_{5}\left(200.40 \mathrm{~g} \mathrm{plant}^{-1}\right)$. 
Table.1 Effect of Azotobacter isolates of different fodder grasses on growth parameters and yield of sweet corn var. Madhu-5

\begin{tabular}{|c|c|c|c|c|c|c|c|c|c|c|}
\hline $\begin{array}{l}\text { Sr. } \\
\text { No }\end{array}$ & Treatment & Treatment details & $\begin{array}{c}\text { Germinatio } \\
\text { n }(\%)\end{array}$ & $\begin{array}{l}\text { Plant } \\
\text { height } \\
\text { (cm) }\end{array}$ & $\begin{array}{l}\text { No. of } \\
\text { leaves }\end{array}$ & $\begin{array}{l}\text { Length } \\
\text { of leaf } \\
(\mathrm{cm})\end{array}$ & $\begin{array}{c}\text { Width } \\
\text { of leaf } \\
(\mathrm{cm})\end{array}$ & $\begin{array}{l}\text { No of } \\
\text { cobs per } \\
\text { plant }\end{array}$ & $\begin{array}{l}\text { Cob yield } \\
\text { per plant }\end{array}$ & $\begin{array}{c}\text { Total } \\
\text { dry } \\
\text { matter }\end{array}$ \\
\hline 1 & $\mathrm{~T}_{1}$ & $\begin{array}{l}\text { Azotobacter isolated from rhizospheric } \\
\text { soil of Napier grass (Phule Gunwant) }\end{array}$ & 89.47 & 144.73 & 12.60 & 95.89 & 10.01 & 2.00 & 265.87 & 37.67 \\
\hline 2 & $\mathrm{~T}_{2}$ & $\begin{array}{l}\text { Azotobacter isolated from rhizospheric } \\
\text { soil of Marvel grass (Phule Goverdhan) }\end{array}$ & 77.19 & 119.07 & 10.00 & 82.84 & 8.95 & 1.07 & 188.07 & 31.73 \\
\hline 3 & $\mathrm{~T}_{3}$ & $\begin{array}{c}\text { Azotobacter isolated from rhizospheric } \\
\text { soil of Anjan grass (Phule Madras } \\
\text { Anajan-1) }\end{array}$ & 78.07 & 140.80 & 10.67 & 80.27 & 8.86 & 1.00 & 163.87 & 27.37 \\
\hline 4 & $\mathrm{~T}_{4}$ & $\begin{array}{l}\text { Azotobacter isolated from rhizospheric } \\
\text { soil of Stylo grass (Phule Kranti) }\end{array}$ & 73.68 & 140.60 & 10.07 & 78.27 & 8.75 & 1.00 & 169.20 & 30.97 \\
\hline 5 & $\mathrm{~T}_{5}$ & $\begin{array}{l}\text { Azotobacter isolated from rhizospheric } \\
\text { soil of Johnson grass (Local) }\end{array}$ & 78.07 & 141.73 & 11.33 & 88.51 & 9.27 & 1.13 & 200.40 & 36.33 \\
\hline 6 & $\mathrm{~T}_{6}$ & $\begin{array}{l}\text { Azotobacter isolated from rhizospheric } \\
\text { soil of Fodder Maize (African tall) }\end{array}$ & 72.81 & 124.27 & 10.47 & 83.60 & 9.06 & 1.07 & 157.47 & 31.87 \\
\hline 7 & $\mathrm{~T}_{7}$ & $\begin{array}{l}\text { Azotobacter isolated from rhizospheric } \\
\text { soil of Fodder Jowar (Ruchira) }\end{array}$ & 64.91 & 139.20 & 10.37 & 84.31 & 9.02 & 1.00 & 183.20 & 28.50 \\
\hline 8 & $\mathrm{~T}_{8}$ & $\begin{array}{l}\text { Absolute control ( No culture or } \\
\text { fertilizer) }\end{array}$ & 53.51 & 117.33 & 9.20 & 71.64 & 7.94 & 1.00 & 121.67 & 25.00 \\
\hline \multicolumn{3}{|r|}{ SE \pm} & 5.06 & 5.74 & 0.51 & 2.85 & 0.27 & 0.09 & 13.95 & 1.52 \\
\hline \multicolumn{3}{|r|}{$\mathrm{CD}(0.05)$} & 15.51 & 17.59 & 1.57 & 8.74 & 0.84 & 0.28 & 42.73 & 4.67 \\
\hline
\end{tabular}


Table.2 Effect of Azotobacter isolates of different fodder grasses on available nitrogen (N), phosphorus $(\mathrm{P})$ and potassium $(\mathrm{K})\left(\mathrm{kg} \mathrm{ha}^{-1}\right)$ and $\mathrm{N}$ uptake $\left(\mathrm{g}\right.$ plant $\left.{ }^{-1}\right)$ in soil at harvest of sweet corn var. Madhu-5

\begin{tabular}{|c|c|c|c|c|c|c|}
\hline $\begin{array}{l}\text { Sr. } \\
\text { No. }\end{array}$ & Treatment & Treatment details & $\mathbf{N}$ & $\mathbf{P}$ & $\mathbf{K}$ & $\begin{array}{l}\text { N uptake } \\
\left(\text { g plant }^{-}\right.\end{array}$ \\
\hline 1 & $\mathrm{~T}_{1}$ & $\begin{array}{l}\text { Azotobacter isolated from rhizospheric soil of Napier grass } \\
\text { (Phule Gunwant) }\end{array}$ & 324.46 & 22.67 & 158.34 & 1.08 \\
\hline 2 & $\mathrm{~T}_{2}$ & $\begin{array}{l}\text { Azotobacter isolated from rhizospheric soil of Marvel grass } \\
\text { (Phule Goverdhan) }\end{array}$ & 187.39 & 19.76 & 102.47 & 0.18 \\
\hline 3 & $\mathrm{~T}_{3}$ & $\begin{array}{l}\text { Azotobacter isolated from rhizospheric soil of Anjan grass } \\
\text { (Phule Madras Anajan-1) }\end{array}$ & 234.37 & 17.36 & 111.03 & 0.20 \\
\hline 4 & $\mathrm{~T}_{4}$ & $\begin{array}{l}\text { Azotobacter isolated from rhizospheric soil of Stylo grass } \\
\text { (Phule Kranti) }\end{array}$ & 240.83 & 20.34 & 103.76 & 0.20 \\
\hline 5 & $\mathrm{~T}_{5}$ & $\begin{array}{c}\text { Azotobacter isolated from rhizospheric soil of Johnson grass } \\
\text { (Local) }\end{array}$ & 244.50 & 12.97 & 165.39 & 0.31 \\
\hline 6 & $\mathrm{~T}_{6}$ & $\begin{array}{l}\text { Azotobacter isolated from rhizospheric soil of Fodder Maize } \\
\text { (African tall) }\end{array}$ & 233.41 & 16.04 & 149.09 & 0.26 \\
\hline 7 & $\mathrm{~T}_{7}$ & $\begin{array}{l}\text { Azotobacter isolated from rhizospheric soil of Fodder Jowar } \\
\text { (Ruchira) }\end{array}$ & 215.34 & 16.98 & 144.03 & 0.15 \\
\hline 8 & $\mathrm{~T}_{8}$ & Absolute control ( No culture or fertilizer) & 174.29 & 14.55 & 102.61 & 0.12 \\
\hline \multicolumn{3}{|r|}{ SE \pm} & 25.588 & 3.831 & 25.953 & 0.09 \\
\hline \multicolumn{3}{|r|}{$\mathrm{CD}(0.05)$} & 78.366 & N.S. & N.S. & 0.27 \\
\hline \multicolumn{3}{|r|}{ Initial value } & 173.98 & 27.92 & 203.35 & \\
\hline
\end{tabular}


The Significant highest total dry matter weight was recorded in treatment $\mathrm{T}_{1}\left(37.67 \mathrm{~g} \mathrm{plant}^{-1}\right)$. The significant least growth was observed in treatment $\mathrm{T}_{8}$ which was control.

\section{Nutrient uptake}

The highest microbial population was observed in treatment $\mathrm{T}_{1}\left(22.66 \times 10^{5}\right)$ shown in table 2 which is followed by treatment $\mathrm{T}_{5}\left(21.66 \times 10^{5}\right)$. The highest nitrogen uptake was recorded in treatment $T_{1}\left(1.08 \mathrm{~g} \mathrm{plant}^{-}\right.$ ${ }^{1}$ )over all other treatments which was followed by the treatment $\mathrm{T}_{5}\left(0.31 \mathrm{~g} \mathrm{plant}^{-1}\right)$.

The studies were undertaken to see the effect of different Azotobacter isolates of different fodder grasses on chemical properties of soil.

The data in table 2 revealed that the available nitrogen content of soil increased significantly over control and there was no effect of Azotobacter isolates of different grasses on phosphorus and potassium content of soil at harvesting stage.

The similar results were found regarding the morphological, biochemical and cultural characters of different Azotobacter strains isolated from rhizospheric soil of grasses, paddy, wheat, ragi, barley, peas, amaranth and turmericby Upadhyay etal. (2015). The results of this study are in line with the studies done by Kizilkaya (2009).

Iwuagwuet al., (2013) reported that, the application of biofertlizers (Azotobacter, Azospirillum and PSM) alone or in combination increased the growth parameters of maize seedlings in terms of plant height and stem base diameter These results agrees with Zahiret al., (2004) that Azotobacter and Azospirillum are the most important plant growth promoting rhizobacteria which affects the growth and development of crops in terms of plant height, number of leaves, length of leaves, width of leaves, fresh and dry weight and yield. Kader et al., (2002) reported that Azotobacter increases $\mathrm{N}$ availability in the soil which could enhance the numbers of grains.

The explosions of Indian population enhance the demand of cereals, pulses, fruits etc. To fulfill this demand of increased population farmers are using excessive amount of fertilizers which directly affecting the soil health and environment, hence to overcome this, we have to go for organic farming with biofertlizers. Mostly Azotobacter biofertilizers are prepared from different Azotobacter isolates isolated from vegetables, cereals, pulses, fruit plants. However the fodder grasses are not considered so far for isolating such microbes. The present research revealed significant results from which it can be concluded that

The rhizospheric soil of Napier grass along with other six grasses has the efficient Azotobacter strains which can be used to produce biofertiliers of Azotobacter.

Seed treatment of biofertilizer prepared from Azotobacter isolate of Napier grass to the sweet corn seeds resulted in increase in plant growth parameters and yield over control.

Seed treatment of biofertilizer prepared from Azotobacter isolate of Napier grass to the sweet corn seeds resulted in increase in nitrogen uptake.

The yield obtained from treatment $\mathrm{T}_{1}$ with Azotobacter isolated from rhizospheric soil of Napier grass (265.87 g/plant) was followed by treatment $\mathrm{T}_{5}$ of Azotobacter isolated from rhizospheric soil of Johnson grass (200.40 g/plant).

The Azotobacter strain of Napier grass can be used to produce biofertiliers of Azotobacter. 


\section{References}

Anonymous., 2017c.National Collateral Management Services Limited (NCoMM) Special report: September 2017).

Azcon, R. and Barea, J. M. 1975. Synthesis of auxins, gibberellins and cytokinins by Azotobacter vinelandii and Azotobacter beijerinckii related to effects produced on tomato plants. Plant and Soil. 43: 609-619.

Dilworth, M.J., Eady, R.R. and Eldridge, M.E. 1998. The Vanadium nitrogenase of Azotobacter chroococcum Reduction of acetylene and ethylene to ethane, Biochem. J. 249: 745-751.

Gonzalez-Lopez, J., Salmeron, V., Martine Toledo, M.V., Ballesteros, F. and Ramos Cormenzana, A. 1986.Production of auxins, gibberellins and cytokinins by Azotobacter vinelandii ATCC12837 in chemically-defined media and dialized soil media, Soil Biol. Biochem. 18:119-120.

Henzell, E.P. and Norris, D. O. 1962. Processes by which nitrogen is added to the soil or plant system. In : Commonwealth Bureao Pasteur and Field Crops, Bull. 46:1-25.

Iwuagwu M., Chukwuka K.S. and Ufere N.U. 2013. Effects of the biofertlizerson the growth of Zea mays L., Asian Jr. of Microbiol. Biotech. Env. Sc. Vol. 15, No. (2): 2013: 235-240.

Kader, M. A., Mian, M. H. and Hoque, M. S. 2002. Effect of Azotobacter inoculants on the yield and nitrogen uptake by wheat. Journal of Biological science. 4: 259-261.
Kizilkaya, R., 2009. Nitrogen fixation capacity of Azotobacter spp. strains isolated from soils in different ecosystems and relationship between them and the microbiological properties of soils. J. Environ. Biol. 30(1): 73-82.

Kukreja, K., Suneja, S., Goyal, S. and Narula, N. 2004. Phytohormone production by Azotobacter-a review, Agric. Rev. 25 (1): 70-75.

Panse, V.G.S. and Sukhatme, V., 1967. Statistical Methods for Agricultural Workers. Indian Council of Agricultural Research. New Delhi. pp. 145-156.

Salle, A.J. 1967. Laboratory manual of Fundamental Principles of bacteriology. McGraw Hill Book., New York.

Sindhu, S.S., Rakshiya, Y.S. and Sahu, G. 2009. Biological control of soil-borne plant pathogens with rhizosphere bacteria. Pest Technol. 3: 10-21.

Upadhyay, S., Kumar, N., Singh, V. K. and Singh, A. 2015. Isolation, characterization and morphological study of Azotobacter isolates. Journal of Applied and Natural Science. 7(2): 984-990.

Varma, A., Kukreja, K., Pathak, D.V., Suneja, S. and Nanda, N. 2001. In vitro production of plant growth regulators by A. chrococcum. Indian Journal of Microbiology. 41: 305-307.

Zahir, A.Z., Arshad, M. and Frankenberger (Jr), W.F. 2004. Plant growth promoting rhizobacteria applications and perspectives in agriculture. Advances in Agronomy, 81: 97- 168.

\section{How to cite this article:}

Potdar, A.R., T.K. Narute, S.N. Hasabanis and Kedar, A.R. 2019. Evaluation of Azotobacter Isolates of Fodder Grasses and its Effect on Sweet Corn Crop. Int.J.Curr.Microbiol.App.Sci. 8(11): 1651-1657. doi: https://doi.org/10.20546/ijcmas.2019.811.191 